\title{
Prestige of social work as profession: Social worker's perspective
}

\author{
Lolita Vilka and Irina Baha \\ Rīga Stradinsš University, Latvia
}

\begin{abstract}
Various studies show that the rating of the social workers profession is not very prestige in comparison with other professions. Often the leading motives why people choose to do social work are those guided by relative ideals, such as the desire to help people or to accomplish something socially significant not because of the prestige of profession. However, judgements about the occupational prestige in the wider community depend largely on the professional beliefs of social workers themselves and on how social workers themselves are positioning their profession. The focus of the authors of this article on the occupational prestige is analysed from the perspective of social workers in the sector. The study was carried out using a quantitative approach. In this study, the occupational prestige is considered in the context of symbolic capital. According to P. Bourdieu all forms of symbolic capital accumulates through relations of exchange The study results indicate that a significant part of the respondents feel the lack of authority and symbolic power. The symbolic capital in the form of professional capital is an essential factor of the authority and symbolic power of the social worker's profession, which, in turn, affects the occupational prestige in the society.
\end{abstract}

Key words: social work, symbolic capital, professional capital, occupational prestige.

\section{Introduction}

The social worker's profession in Latvia was formed in the early 90s of the previous century, when the opportunity to receive professional higher education in social work was created. The decision of the Board of the People's Ministry of Education of the Republic of Latvia of that time "On Opening of the Faculty of Social Workers" (1991) may be considered as formal beginning. But the legitimate recognition of the social worker's profession was achieved several years later.

At that time social work as a professional field of work was not known in the society of Latvia. The task for the first professionals was to socially construct their profession among all the other professions and to gain not only its recognition, but also to demonstrate its pragmatic and practical role and place in tackling social welfare issues.

Since 90s the profession of a social worker has become one of the most important instruments in practical implementation of social policy in modern Latvia, addressing social challenges in the country.

In Latvia, the social worker's profession is not popular among men. However, the dominance of women in the profession of social workers is not observed only in Latvia.

In 2010, a study was carried out in Ireland [1] aimed at identifying why more women were employed in social work than men. The study mentioned that in Ireland in 2005 men 
composed $16.8 \%$ of all the social workers while females constituted $83.2 \%$ of the workforce. The author of the study observed that there are certain prejudices in the viewpoint of men that the social worker's profession is more suited to women, because it is typical of them to tackle various family-related problems, to feel the other person and to seek the opportunity to help emotionally. Whereas, men in the field of social work take more leading positions; but if they work as a social worker, they feel "different" and would like to feel more prestigious in their profession.

In Latvia, there are two categories of specialists in the social work sector: social workers and social work specialists with lower professional qualifications. Most social workers work in municipal social services and their subordinate institutions. But there is also a growing number of social workers working for NGOs, expanding the range of social services. According to the data of the Latvian Association of Local and Regional Governments (LALRG), 1258 social workers were employed in municipal social services in 2015 [2].

Over the last decade, but especially after financial-economic crisis (2008-2011), there are several worrying trends: a lack of social workers, a frequent change of specialists at workplaces, a low interest among young people to study social work, and a small number of students in social work education programmes ${ }^{1}$. From the public viewpoint social work is not regarded as a prestigious professional field of activity. However, judgements about the occupational prestige in the wider community depend largely on the professional beliefs of social workers themselves and on how social workers themselves are positioning their profession.

\section{Occupational prestige}

Prestige is a multifunctional concept with an axiological nature. This is related to valuation and values. The etymology of the word prestige reveals its various characteristics. So, for example, prestigio (ital), means authority, but also includes the idea of magic, charm and fascination. Whereas, the Latin word praestigiae (lat) associates prestige with imaginary characters or illusion.

Prestige may be defined as "a position in the society, relative importance" and as circumstances or a position in terms of significance [3].

In Latvian, prestige is described as the authority, reputation, respect of a person, organisation or institution, as well as the impact of their social role, achievements and power.

Prestige is a condition derived from achievements, associations and power. Whilst we can recognize that it is a desirable condition, and one which we could anticipate enhancing outcomes, it is highly subjective and difficult to measure. It is a relational good, in the sense of not being an absolute quality, but in that its possession or absence is generated within and by relationships. Nonetheless, the effects of prestige are experienced through reputation, and usually take the form of respect and influence [4].

The prestige of an occupation or profession is attributable to the authority of the profession/professional and the public respect for a particular profession. People's perceptions of the status and professional responsibilities of one or another specialist

\footnotetext{
${ }^{1}$ In order to ensure the fulfilment of the requirements defined in laws and regulations regarding the number of qualified social work specialists by 2020 , as well as to ensure sustainable development of professional social work, it is necessary to increase enrolment of students in the first year of studies every year. (According the letter of Welfare Ministry (2013) to the Council of Higher Education and institutions that provide education in the field of social work in Latvia).
} 
constitute a hierarchy of occupations. In sociology, studies on occupational prestige study the social position of a profession in the hierarchy of occupations.

One of the first studies on occupational prestige in Latvia was T. Vilcinsš" "Occupational Prestige and the Choice of Professions Nowadays", carried out in 1965-1966. The study was repeated in 2011, using T. Vilcinsš methodology. 1734 school leavers took part in the survey in 2011. 15 new professions were also incorporated in the study, including social work. The occupational prestige of a social worker was the $67^{\text {th }}$ among the 99 professions.

A similar study was carried out also in Lithuania in 2009. As a result of the study, the rank of a social worker's occupation was approximately in the middle of 66 occupations. The author found in her study that the profession is not particularly prestigious, emphasizing that the social worker's profession is ranked lower than that of a social pedagogue and a psychologist [5].

Various studies show that the rating of the social worker's profession is in the middle rank, neither very high nor too low, in the hierarchy of professions.

These studies disclose the assessment of the occupational prestige from a wider public perspective.

Social workers' opinions and assessment of the social work profession in Latvia have been studied episodically or in the context of other studies. The low prestige of the occupation as one of the problems was mentioned in the study on the period from 2009 to 2011 [6], as well as in the ex-ante studies (2017).

The focus of the authors of this article on the occupational prestige is analysed from the perspective of social workers working in the sector.

\section{Professional prestige in the context of symbolic capital}

In this study, the occupational prestige is considered in the context of symbolic and professional capital. The concept of capital is widely applied in social studies. Four groups of capital are described in P. Bourdieu's work "Social Space": economic, cultural, social and symbolic capital. Other types of capital, including professional capital (W. Schinkel, M. Noordegraaf (2011) [7]; L. Beddoe (2011) [8]; R. Lang, K. Rego, 2015 [9]) and psychological capital (Goldsmith, et al. (1998: 15 [10]), Luthans, et al., 2006, 2007), M. Larson, F. Luthans (2006) [11] are also derived from the concept of Bourdieu's capital.

Symbolic capital, commonly called prestige, reputation, fame, etc., i.e., accumulated prestige or honour (Bourdieu, 1991) [12]. Symbolic capital depends on publicity and appreciation; it has to do with prestige, reputation, honour, etc. It is economic, cultural or social capital in its socially recognized and legitimized form (Bourdieu) [13]. All forms of symbolic capital - prestige, charisma, charm - accumulates through relations of exchange the exchange of services, gifts, attention, care, affection [12].

Symbolic capital - another name for distinction - is nothing other than capital, of whatever kind, when it is perceived by an agent endowed with categories of perception arising from the incorporation of the structure of its distribution, i.e., when it is known and recognized as self-evident [12].

Professional capital is conceptualized as a form of symbolic capital; where prestige, status and influence in both institutional life and the wider public discourse are important to social workers [14].

Strong professional capital gives the profession the symbolic power, attractiveness and sustainability. Symbolic power is a power of "world making." (Bourdieu, 1989) [15]. Symbolic power is a power of constructing reality. Power relations which, in form and content, depend on the material or symbolic power accumulated by the agents (or institutions) 
involved in these relations and which, like the gift or the potlatch, can enable symbolic power to be accumulated. (Bourdieu 1991b) [12].

As with the capital in the economy, augmentation and accumulation of professional capital is also linked to the "movement of capital". It manifests itself in the collaborative process characterised by openness, sharing of knowledge and good practice in the community of professionals.

Among the "key attributes" of the professional capital are the following elements:

- The profession is trusted by others including users of professional services as well as other key stakeholders and other professions;

- Mutually rewarding relationships exist or can be developed with other professional groups;

- Members hold some sense of collective identity and "self-esteem" [14].

The way the professionals themselves perceive the occupational prestige is also an important factor of their professional confidence.

The answers to the following questions were looked for in the study:

- What were the motives for choosing the profession of social workers?

- How do social workers evaluate their power to influence the social situation of the client and decision taking in an interdisciplinary environment?

- How do social workers feel and characterise their occupational prestige from the point of view of their clients and general public?

\section{Methodology of a survey}

The study was carried out in 2017 using a quantitative approach, and the survey was conducted using questionnaires. Practitioners, social workers were asked about the following factors: motives for choosing the profession, authority, respect and symbolic power, remuneration, occupational prestige of a social worker.

200 respondents, who work as a social worker, expressed their views in the survey.

\section{Results}

Of 200 respondents, only 8 men participated in the study. According to the regulatory framework of Latvia, employees who have a professional bachelor's or a professional master's degree in social work can be employed as social workers. However, this regulatory requirement is not always respected. The social service survey shows that in $41 \%$ of cases social services employ social work specialists who have not obtained the education required by law [16].

Of the surveyed specialists, $55.5 \%$ were practitioners having a professional bachelor's degree in social work, $28 \%$ were practitioners with a professional master's degree in social work, $10 \%$ were practitioners who had a bachelor's or master's degree in another field, whereas, $6.5 \%$ of the respondents had a college level professional higher education, but in reality they worked in the position of a social worker. With regard to education $45.5 \%$ of the respondents who did not have education in social work mentioned that they had higher education in another field.

Most respondents have worked in social work for five years and more than five years. This suggests that the views expressed by respondents are based on their professional experience. 
Table 1. Survey results (percentage of responses).

\begin{tabular}{|c|c|c|}
\hline & & Column N \% \\
\hline \multirow{3}{*}{$\begin{array}{l}\text { Power to influence the social situation } \\
\text { of clients }\end{array}$} & 1. Yes, there is power & 18.5 \\
\hline & 2. Sometimes & 68.0 \\
\hline & 3. There is no power to influence & 13.5 \\
\hline \multirow{4}{*}{$\begin{array}{l}\text { Respect of other sector professionals } \\
\text { towards social workers }\end{array}$} & 1. Yes, always & 9.0 \\
\hline & 2. Frequently & 60.5 \\
\hline & 3. Seldom & 29.0 \\
\hline & 4. very seldom & 1.5 \\
\hline \multirow{3}{*}{$\begin{array}{l}\text { Power to influence decisions of senior } \\
\text { management bodies }\end{array}$} & 1. Yes, there is power to influence & 2.5 \\
\hline & 2. Sometimes it is possible to influence & 58.0 \\
\hline & 3. No power to influence & 39.5 \\
\hline \multirow{3}{*}{ Client respect for social workers } & 1. Definitely yes, there is respect & 9.0 \\
\hline & 2. Partly there is respect & 70.5 \\
\hline & 3. No respect & 20.5 \\
\hline \multirow{5}{*}{$\begin{array}{l}\text { The image of a social worker in mass } \\
\text { media }\end{array}$} & 1. Negative & 17.0 \\
\hline & 2. Partly negative & 51.5 \\
\hline & 3. Partly positive & 25.0 \\
\hline & 4. Positive & 6.5 \\
\hline & 5. Very positive & 0.0 \\
\hline \multirow{2}{*}{$\begin{array}{l}\text { Remuneration as a determinative } \\
\text { factor in occupational prestige }\end{array}$} & 1. Yes, it is determinative & 20.0 \\
\hline & 2. It matters, but it is not determinative & 80.0 \\
\hline \multirow{5}{*}{$\begin{array}{l}\text { Assessment of the occupational } \\
\text { prestige of a social worker }\end{array}$} & 1. Not prestigious & 11.5 \\
\hline & 2. Partly non-prestigious & 28.5 \\
\hline & 3. Partly prestigious & 42.5 \\
\hline & 4. Prestigious & 16.0 \\
\hline & 5. Very prestigious & 1.5 \\
\hline \multirow{3}{*}{$\begin{array}{l}\text { Would they change their profession } \\
\text { of a social worker }\end{array}$} & 1. I would agree, without hesitation & 24.5 \\
\hline & 2. I would consider whether to change & 68.0 \\
\hline & 3. Definitely would not change & 7.5 \\
\hline \multirow{3}{*}{$\begin{array}{l}\text { Would they advise their children to } \\
\text { choose the profession of a social worker }\end{array}$} & 1. Yes, definitely would suggest & 4.0 \\
\hline & 2. Would suggest, but not insist & 49.0 \\
\hline & 3. No, in no case would recommend & 47.0 \\
\hline
\end{tabular}

Occupational expectations are important motivational factors in choosing the profession. It was possible to mark one of the three options to the question Why did you choose the profession of a social worker.

The motive desire to help people was mentioned as the most popular reason for choosing the social worker's profession $(23.7 \%)$. Whereas only $2.5 \%$ of the respondents answered that they chose the social worker's profession because they considered it to be prestigious. 
Table 2. Motives for choosing the social worker's profession (percentage of responses).

\begin{tabular}{|l|l|c|c|c|}
\hline \multicolumn{2}{|l|}{} & \multicolumn{2}{|c|}{ Responses } & \multirow{2}{*}{ Percent of Cases } \\
\cline { 3 - 5 } & $N$ & Percent & \\
\hline \multirow{5}{*}{ Motives } & 1. Willingness to be useful to the society & 56 & 11.0 & 28.0 \\
\cline { 2 - 5 } & 2. Willingness to help people & 121 & 23.7 & 60.5 \\
\cline { 2 - 5 } & 3. Willingness to change the society & 30 & 5.9 & 15.0 \\
\cline { 2 - 5 } & 4. Stable pay & 66 & 12.9 & 33.0 \\
\cline { 2 - 5 } & 5. Work in local government & 42 & 8.2 & 21.0 \\
\cline { 2 - 5 } & 6. Vocation & 52 & 10.2 & 26.0 \\
\cline { 2 - 5 } & 7. Workplace near home & 30 & 5.9 & 15.0 \\
\cline { 2 - 5 } & 8. State-funded places in the institution of higher education & 21 & 4.1 & 10.5 \\
\cline { 2 - 5 } & 9. Friend recommendation & 20 & 3.9 & 10.0 \\
\cline { 2 - 5 } & 10. Prestigious profession & 13 & 2.5 & 6.5 \\
\hline & 11. Prior contact with social work & 60 & 11.7 & 30.0 \\
\hline \multicolumn{1}{|c|}{ Total } & 511 & 100.0 & 255.5 \\
\hline
\end{tabular}

$12.9 \%$ of the respondents indicated a stable salary as a motive for their choice of this profession, but $11 \%$ of the respondents mentioned that their choice of profession was determined by their desire to be useful to the society.

$11.7 \%$ of the respondents chose this profession because they had previously come into contact with social work.

It can be assumed that $8 \%$ have chosen the social worker's profession accidentally: some people had the opportunity to take the state-funded places $(4.1 \%)$ in the institution of higher education; others had the recommendation of a friend (3.9\%).

By grouping the motives according to the popularity of the responses, there are four motivational trends:

Vocation (those who claimed that the reason for choosing the profession was vocation (10.2\%); prior contact with social work (11.7\%); willingness to help people (23.7\%));

Social significance and orientation towards change (those who expressed their desire to be useful to the society (11.0\%); willingness to change the society (5.9\%));

Orientation towards stability and security (those whose choice of the profession was determined by a stable salary (12.9\%); work in local government $(8.2 \%)$; work close to home (5.9\%));

Occasional choice (those who had followed the recommendation of friends (3.9\%); or have chosen the profession for the possibility to use a state-funded place in the institution of higher education (4.1\%)).

Respondents whose motivation for choosing the profession was a prestigious profession (2.5\%) most likely focused on externally attractive characteristics of the social worker's profession, so these respondents would rather belong to the occasional choice group.

However, despite various motives, in most cases the choice of the profession can be described as deliberate. 


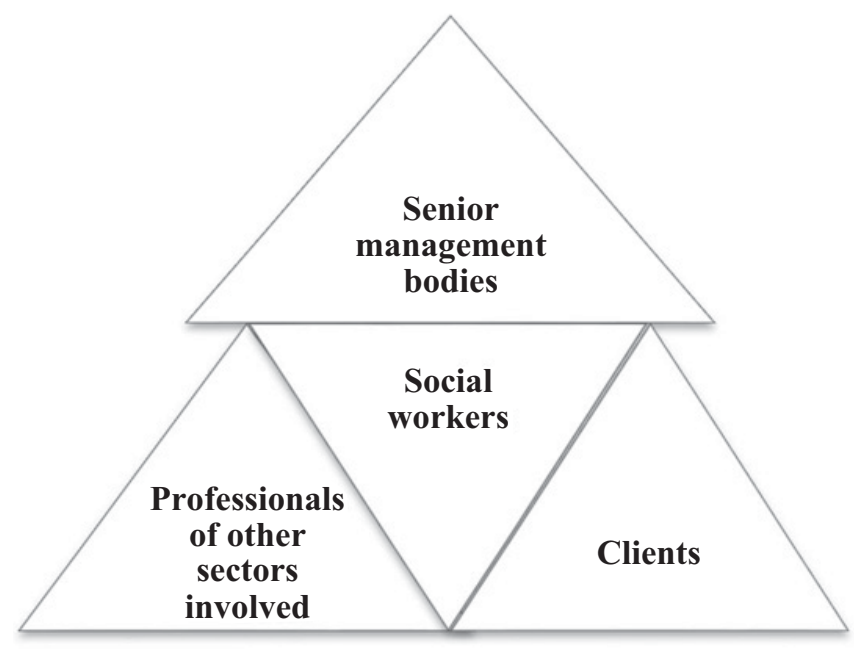

Fig. 1. Social workers in a multi-professional environment.

\section{Authority and symbolic power}

The ability of social workers to tackle social challenges depends on the ability to intervene and influence situations and circumstances. In the development of services, it is important to what extent social workers have the ability, authority and symbolic power to work with their clients, professionals of other sectors and senior bodies in taking decisions.

Relations with service users are an important factor affecting the prestige of the profession. Therefore, the respondents were asked whether their customers respected the social worker's profession.

The majority of the respondents, $70.5 \%$ of those surveyed, claimed that they partly felt the customer respect for social workers, while $20.5 \%$ respondents claimed that clients do not show respect for the social work profession. Only $9 \%$ of those surveyed confirmed that they certainly felt the client respect for social workers.

Thus, there is a reason to believe that social workers are relatively rarely satisfied when working with clients.

Social workers work in a multi-professional environment and in cooperation with senior management bodies on a daily basis.

In this context, it was clarified how social workers value the following three aspects of cooperation:

- the ability of social workers to influence the social situation of their clients,

- respect by professionals of other sectors for social workers,

- the ability of social workers to influence the decisions of senior management bodies.

$13.5 \%$ social workers responded that they had no power to influence the social situation of clients, $68 \%$ social workers believed that sometimes they had power to influence, but only $18.5 \%$ social workers were sure that they were able to influence the social situation of clients.

Regarding professionals of other sectors, $60.5 \%$ of respondents think that representatives of other cooperation organisations and institutions often respect the opinion of social work specialists, while $9.0 \%$ respondents declared that their opinion is always listened to.

Whereas $29.5 \%$ of respondents believed that their opinion was respected rarely, and $1.5 \%$ said that their opinion was very rarely listened to by other institutions. 
Table 3. Willingness to change the social worker's profession in the context of the impact on decision making.

\begin{tabular}{|c|c|c|c|c|}
\hline & \multicolumn{2}{|c|}{$\begin{array}{c}\text { Power to influence the decisions } \\
\text { of superior structures }\end{array}$} & \multirow[t]{3}{*}{ Total } \\
\hline & & \multicolumn{2}{|c|}{ Sometimes it is possible No power to } & \\
\hline & & to influence & influence & \\
\hline \multirow[t]{2}{*}{$\begin{array}{l}\text { 1. I will agree without } \\
\text { hesitation }\end{array}$} & Count & 19 & 30 & 49 \\
\hline & $\%$ within power to influence decisions & 18.1 & 39.5 & 27.1 \\
\hline \multirow{2}{*}{ 2. I will think it over } & Count & 86 & 46 & 132 \\
\hline & $\%$ within power to influence decisions & 81.9 & 60.5 & 72.9 \\
\hline \multirow{2}{*}{ Total } & Count & 105 & 76 & 181 \\
\hline & $\%$ within power to influence decisions & 100.0 & 100.0 & 100.0 \\
\hline
\end{tabular}

Although the majority of respondents considered that they often feel the respect by their colleagues of cooperation organisations, $30.5 \%$ of respondents said that they felt rarely and very rarely respect of the colleagues of their cooperation organisations for social work specialists' opinion.

With regard to the ability of social workers to influence the decisions of senior management bodies, $39.5 \%$ of respondents believe that they have no power to influence their decisions, $58 \%$ said that sometimes it is possible to influence; but only $2.5 \%$ are convinced that they have power to influence the decisions of senior management bodies.

But it is also evident that $27.1 \%$ of the respondents without any reluctance would agree to change the profession of a social worker if they were offered a higher salary in another profession, while $72.9 \%$ of respondents would think about changing the profession. Only $7.5 \%$ respondents claimed they would definitely not change the profession of a social worker to another.

Examining these data with a Chi-Square test ${ }^{2}$, it was possible to conclude that there is a correlation between the power to influence the decisions of senior bodies and the willingness to change the profession of the social worker to another, better paid profession.

Such results indicate that a significant part of the respondents, most likely those social workers who were more inclined to do something socially significant or to bring changes to the society feel the lack of authority and symbolic power of their profession.

In the era of modern technology, it is vital how the profession is positioned in mass media. According to the responses, it is concluded that most respondents believe that the image of their profession is reflected negatively in mass media. The views also were expressed in the ex-ante study (2017) that the prestige of the profession comes from feedback, and there is nothing good in the media about social work [16].

2 A chi-squared test, $\left(\chi^{2}\right.$ test), is any statistical hypothesis test where the sampling distribution of the test statistic is a chi-squared distribution when the null hypothesis is true. The chi-squared test is used to determine whether there is a significant difference between the expected frequencies and the observed frequencies in one or more categories. 
Table 4. Willingness to change the profession of a social worker in the context of remuneration.

\begin{tabular}{|c|c|c|c|c|}
\hline & & \multicolumn{2}{|c|}{$\begin{array}{c}\text { Salary remuneration } \\
\text { as a determinative factor }\end{array}$} & \multirow[t]{2}{*}{ Total } \\
\hline & & $\begin{array}{c}\text { Yes, it is } \\
\text { determinative }\end{array}$ & $\begin{array}{l}\text { It is important, but } \\
\text { not determinative }\end{array}$ & \\
\hline \multirow{2}{*}{$\begin{array}{l}\text { 1. I will agree without } \\
\text { hesitation }\end{array}$} & Count & 22 & 26 & 48 \\
\hline & $\begin{array}{l}\% \text { within salary remuneration } \\
\text { as a determinative factor }\end{array}$ & 56.4 & 18.3 & 26.5 \\
\hline \multirow{2}{*}{ 2. I will think it over } & Count & 17 & 116 & 133 \\
\hline & $\begin{array}{l}\% \text { within salary remuneration } \\
\text { as a determinative factor }\end{array}$ & 43.6 & 81.7 & 73.5 \\
\hline \multirow{2}{*}{ Total } & Count & 39 & 142 & 181 \\
\hline & $\begin{array}{l}\% \text { within salary remuneration } \\
\text { as a determinative factor }\end{array}$ & 100.0 & 100.0 & 100.0 \\
\hline
\end{tabular}

\section{Remuneration as a determinative prestige factor}

$24.5 \%$ of the respondents were ready to change the social worker's profession without hesitation, in the event that they were offered a significantly higher salary in another profession.

Remuneration as a determinative prestige factor was also mentioned in the ex-ante report (2017). One respondent expressed his opinion: "I would like to say that the social work profession is not prestigious, and therefore people do not go to study it. They see all this workload and pay" [17].

In this context, it was clarified whether there is a link between remuneration as a prestige factor and the willingness of social workers to change the profession to another, better paid profession.

By examining with the Chi-Square test, it can be concluded that there is a correlation between the remuneration factor and the willingness to change the social worker's profession to another, better paid one.

However, it should be noted that, despite the fact that $24.6 \%$ of all the respondents were prepared to change their profession without any delay in the event of higher remuneration, they obviously have not had such an offer nor have they themselves looked for a better-paid and more prestigious occupation.

This could suggest that employees are evaluating that it is better to reconcile the profession that has generally low but stable and guaranteed employment and remuneration. Moreover, as mostly women work in the profession, there might be a number of different circumstances for such considerations.

\section{Occupational prestige of a social worker}

In their working experience social workers have looked at the profession from all angles. So the respondents were asked to evaluate how much social work is a prestigious profession.

Most (42.5\%) consider the social worker's profession to be partly prestigious, $15.0 \%$ as prestigious and $1.5 \%$ as very prestigious. It can be seen that the occupational prestige is significantly higher than the prestige rating as a motive for choosing the profession $(2.5 \%)$. 
Table 5. Advise their children / grandchildren to choose the social worker's profession?

\begin{tabular}{|c|c|c|c|c|c|c|}
\hline & \multicolumn{4}{|c|}{ Prestige } & \multirow{2}{*}{ Total } \\
\hline & & $\begin{array}{c}\text { Non- } \\
\text { prestigious }\end{array}$ & $\begin{array}{l}\text { Partly non- } \\
\text { prestigious }\end{array}$ & $\begin{array}{c}\text { Partly } \\
\text { prestigious }\end{array}$ & Prestigious & \\
\hline \multirow{2}{*}{$\begin{array}{l}\text { No, in no case } \\
\text { I would recommend }\end{array}$} & Count & 18 & 31 & 35 & 9 & 93 \\
\hline & $\%$ within Prestige & 78.3 & 57.4 & 42.2 & 30.0 & 48.9 \\
\hline \multirow{2}{*}{$\begin{array}{l}\text { Would recommend, } \\
\text { but would not insist }\end{array}$} & Count & 5 & 23 & 48 & 21 & 97 \\
\hline & $\%$ within Prestige & 21.7 & 42.6 & 57.8 & 70.0 & 51.1 \\
\hline \multirow{2}{*}{ Total } & Count & 23 & 54 & 83 & 30 & 190 \\
\hline & $\%$ within Prestige & 100.0 & 100.0 & 100.0 & 100.0 & 100.0 \\
\hline
\end{tabular}

The assessment of the occupational prestige also shows a relatively high professional confidence in a large part of practising social workers. However, in general, a large number of respondents $(40 \%)$ consider the social worker's profession as partly non-prestigious or non-prestigious.

In the context of the occupational prestige of a social worker, the respondents were asked whether they would advise their children to choose the profession of a social worker.

In this regard, the respondents' answers were divided into two almost equal groups: $48.9 \%$ of the respondents in no case would recommend their children to choose the profession of a social worker, but $51.1 \%$ would, however, leave the choice to their children themselves. Only $4 \%$ of the respondents would definitely recommend their children to choose the profession of a social worker. To a large extent, these answers are related to the prestige of the profession.

\section{Conclusions}

The study leads to the conclusion that it is characteristic of those who choose the social worker's profession to have mutually complementary motives of choice around more or less pronounced leading motive.

Typical leading motives are those guided by relative ideals, such as the desire to help people or to accomplish something socially significant, as well as a realistic orientation towards personal stability and security.

A very small number of the respondents were those for whom the choice of the social worker's profession had an accidental character.

In terms of the motives why people choose to do social work, this study shows a visible gap between the reason possibility to help people and the reason a prestigious profession.

This gap between the possibility to help people (60.5\% of cases) and prestige $(6.6 \%$ of cases) makes you consider the issue from the different point of view, i.e., from the aspect of values: before you get to know the profession of a social worker, helping people is not considered as a prestige value.

If this is a dominant belief not only in the professional environment but also in the wider society (this should be an issue for further in-depth study), it indicates a partial decline in the human values in the society.

In the context of the symbolic capital, helping people should be in those perception categories that give it a value as moral capital and therefore helping people becomes 
prestigious. In this aspect, the occupational prestige of a social worker is related to a wider issue, namely the position of values in the society as a whole.

Although the results of the study all in all show that social workers do not value the prestige of their profession as high, it is evident that, while working and familiarising themselves with the social worker's profession "from within", its prestige rating is significantly higher than in the case of motives for choosing the profession.

The question regarding the willingness to change the social worker's profession to another, better paid profession does not, in itself, indicate that social workers will really change the profession. They still work in the profession and have not left it. However, giving answers to such questions helps identify bottlenecks.

The study shows that social workers are very highly aware of the lack of authority and symbolic power of the profession in relation to clients, professionals of other sectors and senior management bodies.

The relationship between the power to influence decisions of senior management bodies and willingness to change the social worker's profession to another better paid profession points to clearly marked problem. The socioeconomic context suggests that social workers may not have sufficient knowledge and skills to reasonably position social issues at a strategic level in cooperation with senior management bodies. The lack of symbolic power partly explains the manifestation of bureaucracy in the work of social workers, which is often reflected in mass media.

This study shows that social workers are reluctant to wish their children to choose this profession. In Latvia there is no dynasty in the social worker's profession symbolising the power and authority of the profession as is often in the prestigious professions of doctors, lawyers or teachers. The profession of a social worker exists for less than thirty years in Latvia. In terms of symbolic capital, it, however, brings up the questions whether the occupational prestige of a social worker can grow without having the heirs of the profession.

Latvia has adopted a document of social work development policy "Guidelines for Development of Professional Social Work 2014-2020." It reflects the vision of both the general picture and the development of the social work sector. Although the guidelines provide for investment and significant activities, the sustainability and prestige of the profession depends largely on the professional beliefs, motivations and attitudes of the employees in their profession.

A passive, conciliatory position among the professionals themselves does not add to the "good image" of the profession. The promotion of professional capital is an essential factor of the authority and symbolic power of the social worker's profession, which, in turn, affects the occupational prestige in the society.

\section{References}

[1] N. Myers, Crit. Social Think. Policy Pract. 2, 38-58 (2010). Available: https://www.ucc.ie/en/media/academic/appliedsocialstudies/docs/ NiallMyers .pdf [Accessed: 1.07.2018.]

[2] A. Jaunsleinis, Labklājības ministrijai. Riga, 03.11.2016. Nr. 1020162847/A1832 Uz TAP VSS-1004. Available: http://www.lps.lv/uploads/docs_module/2016_ 42_p10.pdf [Accessed: 07.03.2018.]

[3] G. Misāne, M. Gurbo, I. Jemeljanova, I. Dedze, Pētījums par pedagogu profesijas prestižu un iespējām to paaugstināt dažādu mērķauditoriju skatījumā. (2007). Available: www.lizda.lv/content/files/ped_prof_prest_ paaugst_merk_sk.doc [Accessed: 28.03.2017.] 
[4] R. Alistair Anderson, L. Sarah Jack, Int. J. Entrepreneurship Innov. 1(1), 45-56 (2000)

[5] L. Varzinskiene. Socialiniai tyrimai / Soc. Res. 1(15), 98-104 (2009) Available: http://www.su.1t/bylos/mokslo_leidiniai/soc_tyrimai/2009_15/ varzinskiene.pdf [Accessed: 28.03.2018.]

[6] "Sākotnējās ietekmes (Ex-ante) novērtējums par iecerētajām strukturālajām reformām profesionāla sociālā darba politikas jomā” LM/ESF (2012) Available: https : //www . mk.gov.1v/sites/default/files/editor/07122012_4nodevums.pdf [Accessed: 28.03.2018.]

[7] Comp. Sociology 10, 67-96, 87 (2011)

[8] L. Beddoe, Qualitative Soc. Work 12(1), 24-40, 37 (2011)

[9] R. Lang, K. Rego, Zeitschrift für Personalforschung 29(3-4), 259-279 (2015)

[10] H. Arthur, W.D. Goldsmith, Jr., Jonathan, R. Veum. (1998) Race, Cognitive Skills, Psychological Capital and Wages* The Review of Black Political Economy/Fall 1998

[11] M. Larson, F. Luthans, J. Leadership and Organizational Stud. 13(1), (2006)

[12] P. Bourdieu, (1991). Language and Symbolic Power. Edited and Introduced by John B. Thompson Polity Press. Available: https://monoskop.org/images/4/43/ Bourdieu_Pierre_Language_and_Symbolic_Power_1991.pdf [Accessed: 28.03.2018.]

[13] P. Bourdieu, Outline of a Theory of Practice (Cambridge University Press: Cambridge, 1977)

[14] L. Beddoe, N.Z. Sociology 28(2), 2013

[15] P. Bourdieu (1989) Social space and symbolic power. Available: https://www2. southeastern. edu/Academics/Faculty/jbell/symbolicpower . pdf [Skatīts17.07.2018.]

[16] Pašvaldību sociālo dienestu un sociālā darba speciālistu darbības efektivitātes novērtēšanas rezultāti un to analīze. Available: http://www.lm.gov.lv/upload/ projekts/faili/5_gala_zinojums_saskanots.pdf [Accessed: 17.07.2018.]

[17] Profesionāla sociālā darba attīstība pašvaldībās. (2017). Available: http://www. lm. gov.lv/upload/projekts/faili/3_soc_darba_spec_zinojums_saskanots. pdf [Accessed: 17.07.2018.] 